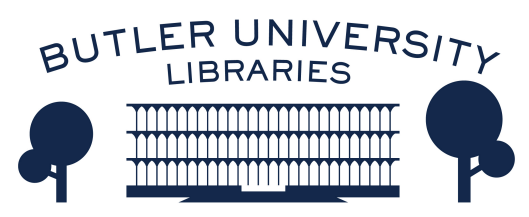

Journal of Hindu-Christian Studies

Volume 26

Article 12

November 2013

\title{
Viewpoint: Learning to be Open to the "Other" at Tiruvannamalai
}

Edward T. Ulrich

University of St. Thomas

Follow this and additional works at: https://digitalcommons.butler.edu/jhcs

Part of the Religion Commons

\section{Recommended Citation}

Ulrich, Edward T. (2013) "Viewpoint: Learning to be Open to the "Other" at Tiruvannamalai," Journal of Hindu-Christian Studies: Vol. 26, Article 12.

Available at: https://doi.org/10.7825/2164-6279.1551

The Journal of Hindu-Christian Studies is a publication of the Society for Hindu-Christian Studies. The digital version is made available by Digital Commons @ Butler University. For questions about the Journal or the Society, please contact cbauman@butler.edu. For more information about Digital Commons @ Butler University, please contact digitalscholarship@butler.edu. 


\section{Viewpoint: Learning to be Open to the "Other" at Tiruvannamalai ${ }^{1}$ Edward T. Ulrich University of St. Thomas}

PEOPLE often tend to project aspects of themselves onto a foreign person or culture. They might see false reflections of themselves in the foreign culture, or instead they might see their own opposites. Also, there is sometimes a tendency to absorb the other party into one's own self-understanding, to reduce the unknown into what is already known, absorbing it into a system. Theorists of crosscultural exchange like Raimundo Panikkar have argued that instead of projecting oneself into the other party or absorbing it into a system of one's own devising that one should be open to something completely new and different in the other culture. This will lead to seeing both the other culture and one's own culture in new and different ways. Thereby one can integrate into one's life the familiar with the new.

This dynamic can be seen in the life of Swami Abhishiktananda (Fr. Henri Le Saux, 1910-1973), who was a well-known monk involved with Hindu-Christian dialogue. Originally he had been a monk at St. Anne's Abbey in Kergonan, France. However, his deep love of monasticism led him in 1948 to come to India to live a more intense form of monasticism than what was practiced at St. Anne's. His concrete goal was to establish a Benedictine monastery that would follow many of the ways of Hindu monasticism, thereby carrying out the goal of "inculturation," a goal that is much discussed in Catholic theological circles.

Having a deep love of monasticism he was excited, in 1949, to meet Ramana Maharshi, who was widely regarded as an exemplary renunciate. He met the Maharshi at his ashram in Tiruvannamalai, but he was disappointed on his first meeting with him because he did not find what he was expecting: "This man seemed so natural, so 'ordinary', a kindly grandfather, shrewd and serene, very like my own. ... But the halo? In vain I strained my eyes trying to see it." ${ }^{2}$ A European woman, Ethel Merstone, advised him that he did not have the right frame of mind, that he had brought too many expectations with him: "You are insisting that what is intended for you should necessarily

Edward Ulrich is a Professor at the University of St. Thomas, where he has been teaching since 2000. He teaches courses on Christianity, other world religions, and interreligious dialogue. He also regularly brings students to India for a world religions course. Having written on Abhishiktananda for his doctoral dissertation, he continues to specialize in him. In addition to contributing articles and book reviews in the Journal of Hindu-Christian Studies he has published in Dilatato Corde, Studies in Interreligious Dialogue, Horizons: the Journal of the College Theology Society, and International Journal of Hindu Studies. He is currently researching how Keshub Chandra Sen's views of Hindu image worship changed during his life. 
come to you by the path which you have determined. Instead you should make yourself empty; simply be receptive."3 On the next day, Abhishiktananda sat, for a second time, in one of the sessions for darśan. That time it was a meaningful experience. In his words: "Even before my mind was able to recognize the fact, and still less to express it, the invisible halo of this Sage had been perceived by something in me deeper than any words. . . . it was as if the very soul of India penetrated to the very depths of my own soul." ${ }^{4}$ On that day Abhishiktananda began to develop an appreciation of Advaita Vedanta, and came to spend the next 23 years, until his death, engaged in a deep, interior dialogue between Advaita and Christian faith.

My own inter-religious journey parallels somewhat that of Abhishiktananda's, though it is colored differently by my professional foci. On my part, I was exposed to a variety of religions in childhood and later came to pursue a career as an academic in comparative studies. In 2001 I finished my doctoral dissertation on Swami Abhishiktananda, and in 2005 took the first of five trips to India. My experiences at Tiruvannamalai on my first and second trips, 2005 and 2007, exhibited a similar dynamic as Abhishiktananda's. To demonstrate this I will describe my background more.

I was raised as a Roman Catholic and was particularly interested in the philosophical dimensions of it. I was exposed at an early age to Neoplatonism, and so my outlook was shaped by the idea of emanation from and return to "the One." Further, I had as a spiritual goal the ascent of the mind along the path of return, ascending from earthly realities to the contemplation of supernal beauty. I considered the rituals and pageantry of the Catholic Church as a route on that path of return, just as the Neoplatonists of antiquity, both pagan and Christian, considered the rituals of their respective religions as routes on that return.

Catholicism was not the only religious influence on me in my childhood. I was growing up in the 1970s, the era of the counterculture, and through a brother sixteen years older than me I became involved with the Meditation Center in Minneapolis, which was directed by Usharbudh Arya (now Swami Veda Bharati). Through the Center I learned to practice various meditative techniques and became familiar with certain classic works, like the Upanishads.

It was clear to me that there were inconsistencies between the Catholic and Hindu realms I was involved with, but there was also a conflation of the two worlds in my mind. In certain ways, I read my Western world into the Eastern classics, dressing them up in Western clothing and giving them a Western interpretation whenever I lacked the knowledge to do otherwise. Graduate school gave me the knowledge and theoretical apparatus to avoid this projection, but it was not until my visit to Tiruvannamalai that I learned the fuller extent of this conflation. This came about through the contrast between what I experienced at Tiruvannamalai and what I expected.

My expectations were shaped by St. John's Abbey in Minnesota, which had been founded by Benedictine monks from Germany in the nineteenth century. My father had been educated by monks from this Abbey, I had been making visits there with family since childhood, and I had graduated from there. The setting is beautiful, for it is at the shores of a lake where hills and woodlands meet the prairie. Located at the edge of the forest, the 
grounds are quiet, except for the occasional groups of passerby and the bells that mark the hours and quarter hours. The grounds and buildings are kept in immaculate condition. The site exudes a sense of order as the monks follow the alternating periods of work, rest, and communal prayer, as prescribed by the Rule of Benedict.

My expectations of a site of spiritual retreat were shaped by St. John's, but I found Tiruvannamalai to be a very different place. To begin, the landscape of the northeastern region of Tamil Nadu is monotonous, consisting of flat plains punctuated by low hills, in endless succession. Tiruvannamalai has been considered a great holy site for centuries, and a main focus is the hill or low lying mountain, Arunachala. However, on approaching Tiruvannamalai there is nothing distinctive to mark it off from its surroundings, no dramatic break. Arunachala stands alone, apart from the other hills, but it resembles them closely.

One is also struck by a plainness or ordinariness in walking the pilgrimage route around the mountain. Dotting the route are many shrines and pillared halls, the latter having been built as places of rest and leisure. The interiors of the shrines house stone lingas and are small, dark, and unadorned. I realized what Abhishiktananda had stated in in describing a small Shaivite shrine, "Here there was indeed nothing to interest the archaeologist, still less the lover of the gaudy." At the end of the route I walked through the haze that rises from the cremation grounds, just outside the city, which left me with a sober feeling.

The Annamalaiyar temple inside the city is an exception to the plainness of the site. It is an enormous complex that was built over many centuries. It features an abundance of shrines and towers, which are carved in intricate detail. Leaving behind the grandeur of the outer courts, the environment in the inner halls is dark and mysterious. The fervor of the worshippers in those halls is impressive.

Leaving behind the temple one comes to Ramanasram. The environment is quiet and peaceful, but there is nothing distinctive marking the ashram off from its general surroundings, just as there is nothing distinctive marking Tiruvannamalai itself off from its surroundings. Further, the focal point is Ramana, but as Abhishiktananda pointed out, there was nothing particularly striking about his appearance, just as there was nothing striking about the mountain and its many shrines. Yet, in the small chamber housing Raman's couch I was impressed by the intensity of the people, which included many samnyāsins, who were seated in meditation.

As my first day at Tiruvannamalai drew to an end I thought to myself, "This is an alien place. I do not belong here." I felt also disappointed, just as Abhishiktananda had felt disappointed on his first day there. These reactions surprised me, since I had practiced meditation since childhood and had read extensively about Tiruvannamalai in conjunction with my dissertation. However, just like Abhishiktananda had earlier, I came with too many expectations. I expected something striking like St. John's. I expected it to be different from St. John's but arresting all the same. Being so ordinary in appearance, Tiruvannamalai did not speak to me of ultimate reality on that first trip. However, I knew that it speaks to others of ultimate reality, and so I wanted to find what others saw in the site. 
I reflected more on Abhishiktananda's writings, and during my second trip in 2007 I came to appreciate Tiruvannamalai and to enter into its spirit. Abhishiktananda explained the plainness and simplicity of the lingas in the Shaivite shrines, stating that "the linga is at the same time 'with' and 'without form', as is taught by the Tamilian Shaivite catechisms. It stands at the boundary between the Manifested and Non-manifested, the last threshold that can be discerned through sight or touch by anyone who has sensed the presence of the essential Beyond." Lingas and their dark chambers are, according to him, invitations to go "beyond our own personal vision of God, beyond all 'recollection' even of ourselves, it is the very mystery of God in himself, of God in his true deity, his unoriginate being, his ineffable nature." The lingas call us to go beyond even "joy and the thought of joy and every feeling of joy."7

Abhishiktananda's words led me to reflect more deeply on Ramana. The man, the ashram, the mountain, and the general surroundings are plain and ordinary looking. This general appearance mirrors an aspect of Ramana's character and teachings. To begin, he had a humility that led to impartiality. For instance, a biographer described the general environment at the sessions for darśan by stating that "a group of pandits sit near the couch, translating a Sanskrit work, and from time to time take it up to him to elucidate some point. A threeyear-old, not to be outdone, takes up his story of Little Bo Peep, and Sri Bhagavan takes that too, just as graciously, and looks through it with the same interest." ${ }^{8} \mathrm{He}$ sometimes deflated people who put questions of belief and practice to him by informing that they were missing the key point, which is an understanding of the self; nothing matters next to that. ${ }^{9}$ Also, his preferred method of teaching was not anything extraordinary but rather sitting in silence with disciples and visitors. ${ }^{10}$ Presumably he behaved and acted in these ways because he considered self-knowledge alone to be essential, and did not want to draw attention to much else than that. Also, one could add to this the point that if one considers one thing to be grand or to be greater than another thing one has departed from the vision of the self being all; one has departed from non-duality.

These considerations helped me to appreciate the general environment at Tiruvannamalai. The great natural beauty at St. John's may inspire one to scale Neoplatonic heights. However, could that beauty be a distraction from God? Also, the environment at St. John's is comforting, due to the general sense of quiet, order, and cleanliness that pervade. Tiruvannamalai is not like that; the city is large and busy, the hubbub in the outer courts of the temple loud, and the samnyāsins unkempt in appearance. However, does a site have to speak of comfort to speak of God? Instead, Abhishiktananda wrote of going beyond "joy and the thought of joy and every feeling of joy."

I will not plunge into the depths of formlessness that Abhishiktananda did, but will remain at the periphery of such experiences as a scholar. However, these considerations affect my outlook. For instance, I've come to see my own religion with new eyes. Jesus, for example, was a peasant from Galilee, which was considered a backwards place by those in Jerusalem. Further, he might thus have been plain and ordinary in appearance, like the Maharishi. The people he gathered as disciples were not philosophical elites but Galilean 
fishermen, concerned with the practicalities of daily living. The key prayer Jesus taught, the "Our Father," is simple and humble in spirit, petitioning God for the most basic of things, such as one's daily bread and the forgiveness of sins. Further, the central symbol in Christianity, the cross, is essentially plain and

\section{Notes}

${ }^{1}$ I am grateful to the University of St. Thomas and the Upper Midwest Association for International Education, whose funding made the trips to India discussed herein possible.

${ }^{2}$ Abhishiktananda, The Secret of Arunāchala: A Christian Hermit on Shiva's Holy Mountain (Delhi: ISPCK, 1979), pp. 5-6.

${ }^{3}$ Ibid., p. 8.

${ }^{4}$ Ibid., p. 8.

${ }^{5}$ Abhishiktananda, Guru and Disciple: An Encounter with Srī Gnānānanda, a Contemporary Spiritual Master (Delhi: ISPCK 1990), p. 51.

${ }^{6}$ Abhishiktananda, Guru and Disciple, p. 39. See also Shiva Purana, Vidyeshvara Samhita 5.

${ }^{7}$ Abhishiktananda, Guru and Disciple, p. 45.

${ }^{8}$ Arthur Osborne, Ramana Maharshi and the Path of Self-Knowledge (Boston: Weiser Books, 1970), p. 130.

'Osborne, Ramana Maharishi, p. 155; Ramana Maharishi, and Arthur Osborne, ed., The Teachings of Bhagavan Sri Ramana Maharshi in His Own Words, 2d ed. (Tiruvannamalai: Sri Ramanasramam, 1965), pp. 62, 200; Joel D. Mlecko, "The Educational Role of the Guru in Hindu Spiritual Development as Exemplified in the Life and Teachings of Sri Ramana Maharshi" (PhD diss., Catholic University of America, 1975), p. 111.

${ }^{10}$ Mlecko, "Educational Role" pp. 110, 117-21.

${ }^{11}$ Abhishiktananda, Guru and Disciple, p. 45. simple, and was originally an instrument of torture and death, hardly something to inspire one to climb Neoplatonic heights. In summary, a main effect of my India trips on my practice of Christianity has been to make it more grounded and down-to-earth. 